\title{
Nitrogen balance studies in apparently healthy elderly people and those who are housebound
}

\author{
BY VALDA W. BUNKER ${ }^{1}$, MARGARET S. LAWSON², MAUREEN \\ F. STANSFIELD ${ }^{3}$ AND BARBARA E. CLAYTON ${ }^{1}$ \\ ${ }^{1}$ Department of Chemical Pathology and Human Metabolism, and ${ }^{3}$ Department of \\ Geriatric Medicine, Medical Faculty of the University of Southampton, Level D, South \\ Laboratory Block, Southampton General Hospital, Southampton SO9 $4 X Y$ \\ ${ }^{2}$ Department of Food and Biological Sciences, The Polytechnic of North London, \\ London $N 87 D B$
}

\section{(Received 31 January 1986 - Accepted 16 October 1986)}

\begin{abstract}
1. Metabolic balance studies ( $5 \mathrm{~d}$ ) for nitrogen were carried out in twenty-four apparently healthy elderly people (age 69.7-85.6 years) and a heterogeneous group of twenty housebound elderly people (age 69.9-85.1 years) with chronic diseases. During the study all subjects ate self-selected diets, lived in their own homes and continued their normal daily activities. Seven of the housebound received meals-on-wheels $5 \mathrm{~d} /$ week.

2. Healthy men and women had mean metabolizable energy intakes of 8.7 and $6.6 \mathrm{MJ} / \mathrm{d}$ respectively compared with 6.3 and $4.8 \mathrm{MJ} / \mathrm{d}$ in the housebound. The average energy content of the meals-on-wheels as delivered was $2.4 \mathrm{MJ}$ per meal, of which $2 \cdot 1 \mathrm{MJ}$ were consumed.

3. The healthy men and women had average daily protein intakes of 69.4 and $59.7 \mathrm{~g}$ respectively compared with $46 \cdot 3$ and $39 \cdot 1 \mathrm{~g}$ in the housebound. Meals-on-wheels as supplied provided $19.4 \mathrm{~g}$ protein per meal, of which $16 \cdot 2 \mathrm{~g}$ were consumed.

4. Healthy subjects were in equilibrium for $\mathrm{N}$ balance $(0 \mathrm{mmol} / \mathrm{d})$ with a daily intake of $733 \mathrm{mmol}$, which was equivalent to $11.04 \mathrm{mmol} \mathrm{N}(0.97 \mathrm{~g}$ mixed protein $) / \mathrm{kg}$ body-weight per d. Housebound individuals were in negative $\mathrm{N}$ balance $(-95 \mathrm{mmol} / \mathrm{d})$ with an intake of $475 \mathrm{mmol} / \mathrm{d}$, corresponding to $7.59 \mathrm{mmol} \mathrm{N}(0.67 \mathrm{~g}$ mixed protein) $/ \mathrm{kg}$ body-weight per $\mathrm{d}$.

5. We were unable to determine in the present study whether the negative $\mathrm{N}$ balance observed in the housebound people was due to the relatively low $\mathrm{N}$ intake or the underlying disease condition.
\end{abstract}

In the UK, $12 \%(6000000)$ of the total population are aged 65 years or over (Morgan, 1983), of whom about $8 \%$ are housebound (Exton-Smith, 1980). The latter have been identified as being particularly vulnerable to malnutrition. Relatively little is known about the nutritional needs of the elderly, the existing information being extrapolated mainly from studies in healthy younger people. In particular, there is little information about the effect of the common chronic diseases of old age on these requirements.

Ageing affects body composition, tissue function, metabolism and nutrient requirements (Munro, 1981). There is wide individual variation (Durnin, 1983), but, in general, as people age there is a decline in the basal metabolic rate and physical activity with a corresponding reduction in energy requirement. There is a decrease in total body protein with age (Munro, 1983), with the skeletal muscle being primarily affected. Whether dietary protein requirements alter with age is not established, although Chinn et al. (1956) using labelled albumin were unable to show any significant difference in protein digestion and absorption between young and old. Protein requirements may be assessed by the factorial method which measures obligatory nitrogen loss while subjects are sustained on a protein-free diet, or the minimum amount of protein needed in the diet to produce $\mathrm{N}$ balance may be determined. Results obtained using the former method tend to suggest that requirements of young and old are similar (Calloway \& Margen, 1971; Scrimshaw et al. 1972, 1976; Uauy et al. 1978a; Zanni et al. 1979). Recent work has suggested that the amount of protein required to achieve $\mathrm{N}$ balance ranges from 0.57 (Zanni et al. 1979) to over $0.8 \mathrm{~g}$ egg protein $/ \mathrm{kg}$ body-weight 
Table 1. Characteristics of healthy and housebound subjects studied

(Mean values and ranges)

\begin{tabular}{|c|c|c|c|c|c|c|c|c|}
\hline & \multicolumn{4}{|c|}{ Healthy } & \multicolumn{4}{|c|}{ Housebound } \\
\hline & \multicolumn{2}{|c|}{ Males ( $n$ 11) } & \multicolumn{2}{|c|}{ Females (n 13) } & \multicolumn{2}{|c|}{ Males $(n 7)$} & \multicolumn{2}{|c|}{ Females ( $n$ 13) } \\
\hline & Mean & Range & Mean & Range & Mean & Range & Mean & Range \\
\hline Age (years) & $78 \cdot 2$ & $70 \cdot 1-85 \cdot 2$ & $75 \cdot 8$ & $69 \cdot 6-85 \cdot 4$ & $78 \cdot 8$ & $69 \cdot 9-85 \cdot 1$ & $78 \cdot 8$ & $70 \cdot 5-82 \cdot 9$ \\
\hline Wt $(\mathrm{kg})$ & 69.9 & $57 \cdot 9-86 \cdot 5$ & 64.0 & $45 \cdot 0-78 \cdot 2$ & $67 \cdot 8$ & $50 \cdot 8-82 \cdot 6$ & $63 \cdot 0$ & $40.0-88.9$ \\
\hline Height $(\mathrm{m})$ & 1.74 & $1.58-1.82$ & $1 \cdot 61$ & $1 \cdot 49-1 \cdot 71$ & 1.74 & $1.68-1.78$ & 1.56 & $1 \cdot 36-1 \cdot 70$ \\
\hline $\begin{array}{l}\text { Quetelet } \\
\text { index* }\left(\mathrm{kg} / \mathrm{m}^{2}\right)\end{array}$ & $22 \cdot 7$ & $19 \cdot 9-27 \cdot 0$ & $24 \cdot 5$ & $19 \cdot 4-28 \cdot 7$ & $22 \cdot 1$ & $16 \cdot 1-26 \cdot 8$ & $25 \cdot 3$ & $18 \cdot 5-34 \cdot 2$ \\
\hline
\end{tabular}

* Body-weight/height ${ }^{2}$.

per d (Gersovitz et al. 1982). These investigations have generally been carried out in specialized metabolic units whilst the subjects ate defined formula diets. Some studies have also included subjects with chronic disease (Uauy et al. 1978 b; Gersovitz et al. 1982), many of them receiving therapeutic drugs. These are all factors which may in themselves affect $\mathrm{N}$ balance.

The objective of the present investigation was to study the dietary intake and requirement of protein in old people by carrying out metabolic balance studies for $\mathrm{N}$ in a group of housebound people with chronic diseases and comparing the results with those obtained in a group of apparently healthy active individuals.

\section{SUBJECTS, MATERIALS AND METHODS}

\section{Subjects}

Details of the two groups of subjects are given in Table 1.

The healthy group was free from any apparent disease, although one woman was subsequently shown to have mild hyperglycaemia. They lived unsupported in their own homes, and purchased and prepared their own food. Preliminary information for ten of these subjects has been published previously (Bunker et al. 1982) and is included in the present study.

Subjects in the second group were classified as housebound if they were unable to go out unaccompanied. This was generally due to physical infirmity, although two people were suffering from severe depression. The subjects were suffering from various stable chronic disorders such as osteoarthritis and chronic obstructive airways disease. Individuals known to have hepatic, renal or gastrointestinal disease, malignancies or acute illness were not included. The subjects were taking various medications including tranquilizers, diuretics and anti-inflammatory drugs. Sixteen of them received home-help once or twice a week. Food was bought by friends, relatives, home help or the subjects themselves when they were taken out. Three men and four women received meals-on-wheels $5 \mathrm{~d} /$ week and another woman ate at a luncheon club $1 \mathrm{~d} /$ week.

The study was approved by the Joint Ethical Sub-Committee of the Faculty of Medicine of the University of Southampton, and Southampton and South-west Hampshire Health Authority. 


\section{Sample collection and analysis}

Balance material. Metabolic balanced studies ( $5 \mathrm{~d}$ ) were carried out as previously described (Bunker et al. 1982, 1984). Where a subject received meals-on-wheels two portions were delivered, these were combined and divided, any of the food not eaten being saved separately. Seven subjects received such meals; the five meals corresponding to each subject were homogenized and analyzed. Therefore although thirty-five different meals were collected, the means and standard deviations quoted for the meals-on-wheels refer to these seven batches each containing five meals.

It was necessary to spend a great deal of time with the subjects, particularly those who were housebound, to ensure reliable collection of samples. Great care was taken however not to encourage the subjects to alter their normal eating habits.

Analysis. Analyses were performed in triplicate.

Gross energy was determined in freeze-dried samples using a bomb calorimeter (Gallenkamp, London). The mean within and between batch precisions for analysis were $3 \cdot 1$ and $4.2 \%$ respectively. Metabolizable energy was calculated using the formula of Miller \& Payne (1959) converted to SI units:

Metabolizable energy $(\mathrm{kJ})=($ gross energy $(\mathrm{kJ}) \times 0.95)-(\mathrm{N}(\mathrm{mmol} \times 0.0044))$.

All results are given as metabolizable energy.

Samples were analyzed for $\mathbf{N}$ using a semiautomated Kjeldahl technique (Tecator, Bristol). The mean within batch precisions for analysis of $\mathrm{N}$ in dietary, faecal and urinary homogenates were $1.6,1 \cdot 5$, and $0.9 \%$, with mean recoveries of $\mathrm{N}$ (as ammonium sulphate) added to the samples before analysis being $97.5,98.0$ and $99.0 \%$ respectively. The daily protein intake was calculated from the $\mathrm{N}$ value: protein $(\mathrm{g} / \mathrm{d})=\mathrm{N}(\mathrm{mmol} / \mathrm{d}) \times 0.0875$.

\section{Statistical analysis}

Multiple regression analysis was used to assess the independent effects of health, sex and body-weight on the data, association between variables was determined using Pearson's correlation coefficient $(r)$ and a paired $t$ test was used to assess the significance of the retention values obtained (Armitage, 1971). A probability level of 0.05 was accepted as significant.

\section{RESULTS}

\section{Energy}

Table 2 compares the energy intakes expressed in $\mathrm{MJ} / \mathrm{d}$ and $\mathrm{kJ} / \mathrm{kg}$. Men consumed more energy than women even when differences in body-weight were taken into account. The daily energy intake of the housebound elderly was less than that of the healthy people. The dietary intake of energy (independent of health, sex and body-weight) correlated with protein intake $(P<0.001)$. The meals-on-wheels as served provided a mean energy intake (SD) of 2.4 $(0.3)$, with a range of 1.9 to $2.7 \mathrm{MJ} / \mathrm{d}$. A varying proportion of the meal was discarded and the meals-on-wheels as eaten provided $2 \cdot 1(0 \cdot 3) \mathrm{MJ} / \mathrm{d}$, this quantity averaging $40(13) \%$ of the total daily energy intake.

Within the housebound group of people there was no difference between the energy intakes of the subjects who received meals-on-wheels and those who did not.

\section{Protein}

Table 2 compares the daily protein intake expressed in $\mathrm{g} / \mathrm{d}, \mathrm{g} / \mathrm{kg}$ body-weight and $\mathrm{g} / \mathrm{MJ}$. Men consumed more protein than women on a daily basis but the difference disappeared 


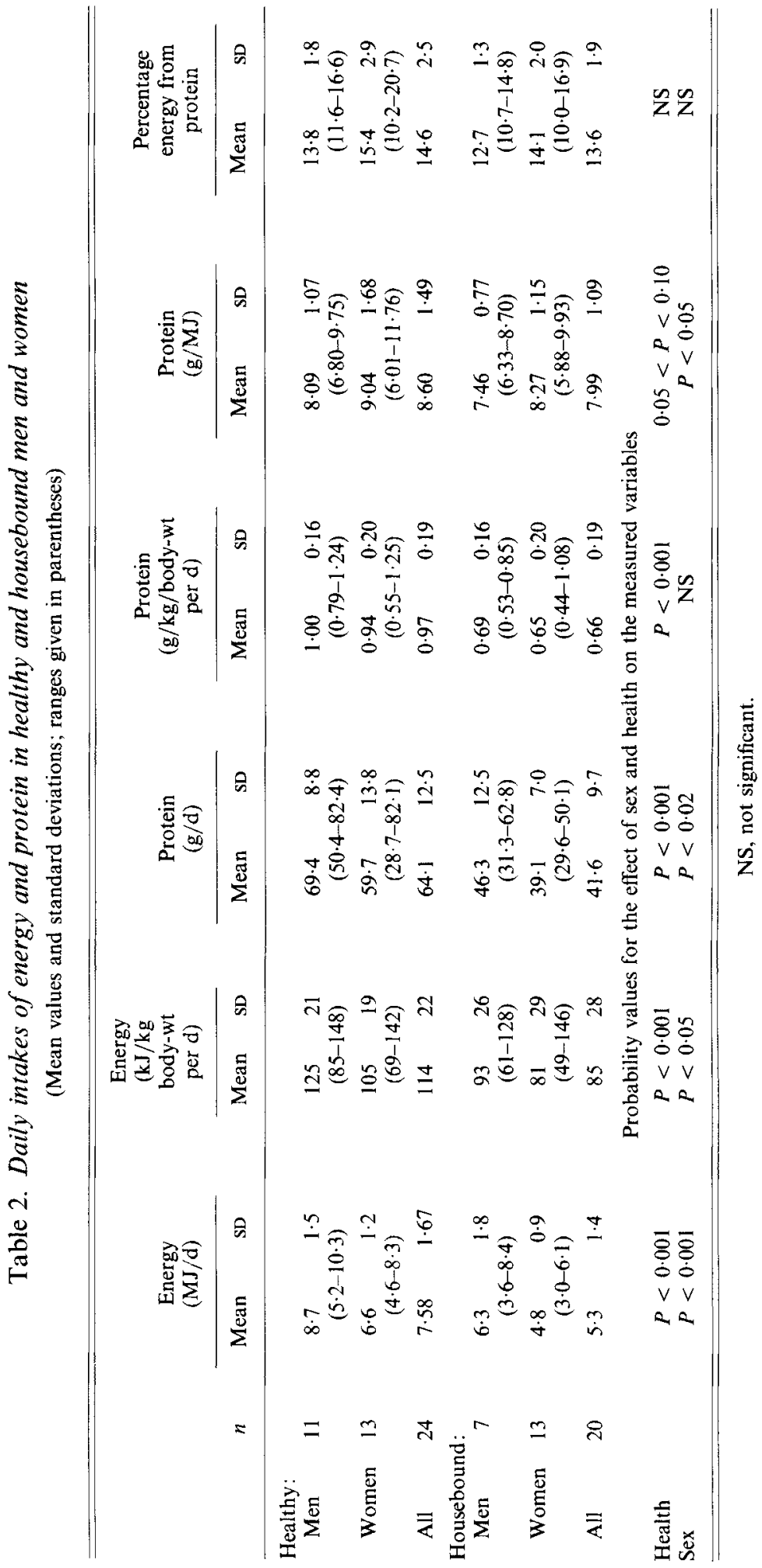




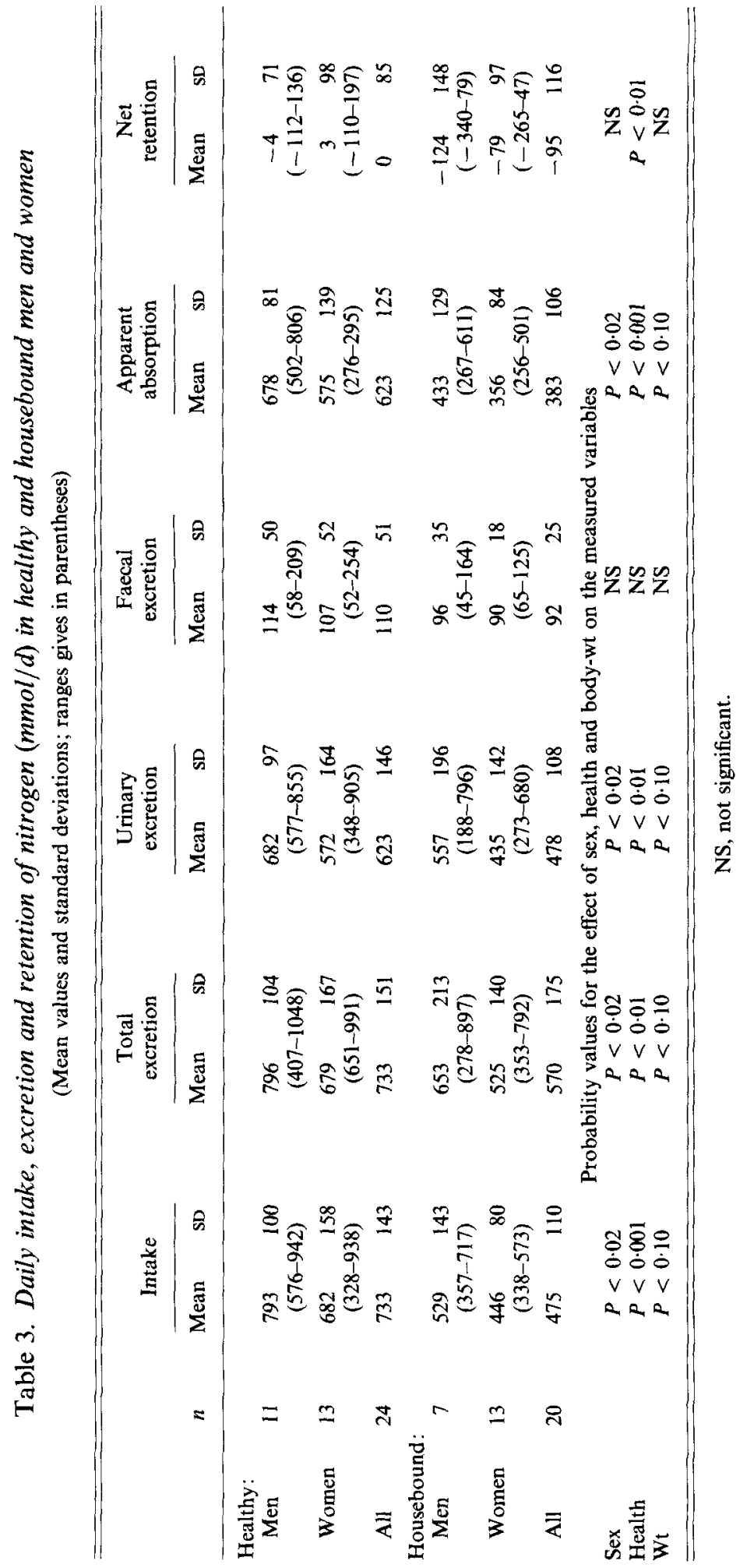




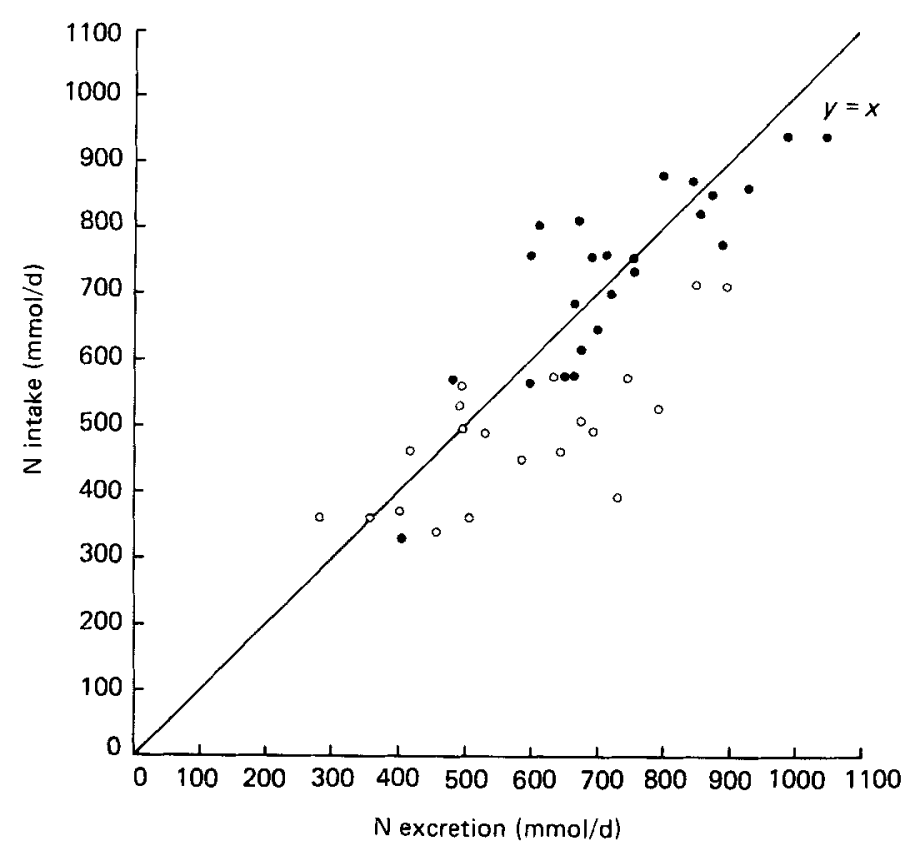

Fig. 1. Daily nitrogen balance in twenty-four healthy $(\odot)$ and twenty housebound $(O)$ elderly subjects.

when expressed in terms of body-weight and was reversed when considered in terms of nutrient density (i.e. women ate a more protein-dense diet). The housebound elderly consumed less protein and ate a slightly $(0.05<P<0.10)$ less protein-dense diet than those who were healthy.

Meals-on-wheels as delivered provided a mean (SD) protein content of $19.4(1.6) \mathrm{g}$, with a range of $17-21 \mathrm{~g}$. The meals actually consumed provided $16 \cdot 2(2 \cdot 7) \mathrm{g}$, which was $43(12) \%$ of the mean total daily protein intake. There was no difference in the daily protein intakes of the subjects who received meals-on-wheels and those who did not.

In both groups of subjects protein provided a fairly constant percentage of the total energy intake (Table 2).

\section{$N$ balance}

Table 3 gives the results of the $\mathrm{N}$ balances and shows the individual effects of health, sex and body-weight on the results. Fig. 1 shows the scatter of points for the two groups of subjects about the line of equilibrium $(y=x)$. The overall mean $\mathrm{N}$ intake and retention of the healthy group was 733 and $0 \mathrm{mmol} / \mathrm{d}(11.04$ and $0.05 \mathrm{mmol} / \mathrm{kg}$ body-weight per $\mathrm{d})$ respectively. The scatter of points about the line of equilibrium was not significant, i.e. the group as a whole was in balance for $\mathrm{N}$. The mean $\mathrm{N}$ intake in the housebound group was $475 \mathrm{mmol} / \mathrm{d}(7.59 \mathrm{mmol} / \mathrm{kg}$ body-weight per d) with a balance of $-95 \mathrm{mmol} / \mathrm{d}$ $(-1.37 \mathrm{mmol} / \mathrm{kg}$ body-weight per $\mathrm{d})$, a value which did differ from equilibrium $(P<0.01)$. Table 3 shows that health and sex had a marked effect on intake, excretion, absorption and retention of $\mathrm{N}$, and body-weight a lesser effect. Multiple regression analysis showed that all the differences in excretion and absorption resulted from variations in $\mathrm{N}$ intake. There was no correlation between $\mathrm{N}$ retention and the dietary intake of either energy or N.

Within the housebound group the $\mathrm{N}$ retentions of those subjects (three men, three women) whose $\mathrm{N}$ intake exceeded the Food and Agriculture Organization/World Health 
Table 4. Daily protein and energy intakes of subjects in the present study compared with other similar studies in the UK

(Mean values and standard deviations)

\begin{tabular}{|c|c|c|c|c|c|c|c|}
\hline \multirow[b]{3}{*}{ Reference } & \multirow{2}{*}{\multicolumn{3}{|c|}{ Subjects }} & \multicolumn{4}{|c|}{ Daily intake } \\
\hline & & & & \multicolumn{2}{|c|}{ Protein $(\mathrm{g} / \mathrm{d})$} & \multicolumn{2}{|c|}{ Energy $(\mathrm{MJ} / \mathrm{d})$} \\
\hline & $n$ & Sex & $\begin{array}{c}\text { Age } \\
\text { (years) }\end{array}$ & Mean & SD & Mean & SD \\
\hline $\begin{array}{l}\text { Healthy: } \\
\text { Present study }\end{array}$ & $\begin{array}{l}11 \\
13\end{array}$ & $\begin{array}{l}\text { Male } \\
\text { Female }\end{array}$ & $\begin{array}{l}70-85 \\
70-85\end{array}$ & $\begin{array}{l}64 \cdot 9 \\
59 \cdot 7\end{array}$ & $\begin{array}{r}8.8 \\
13 \cdot 8\end{array}$ & $\begin{array}{l}8 \cdot 7 \\
6 \cdot 6\end{array}$ & $\begin{array}{l}1 \cdot 5 \\
1 \cdot 2\end{array}$ \\
\hline $\begin{array}{l}\text { Exton-Smith \& } \\
\text { Stanton, } 1965\end{array}$ & 60 & Female & $75 \cdot 9$ & $57 \cdot 0$ & - & 7.9 & -- \\
\hline $\begin{array}{l}\text { Macleod et al. } \\
1974\end{array}$ & $\begin{array}{r}77 \\
187\end{array}$ & $\begin{array}{l}\text { Male } \\
\text { Female }\end{array}$ & $\begin{array}{l}>65 \\
>65\end{array}$ & $\begin{array}{l}78 \cdot 0 \\
60 \cdot 0\end{array}$ & $\begin{array}{l}20 \cdot 0 \\
13 \cdot 0\end{array}$ & $\begin{array}{l}9 \cdot 7 \\
7 \cdot 3\end{array}$ & $\begin{array}{l}3 \cdot 4 \\
1 \cdot 8\end{array}$ \\
\hline $\begin{array}{l}\text { Lonergan et al. } \\
1975\end{array}$ & $\begin{array}{l}54 \\
67\end{array}$ & $\begin{array}{l}\text { Male } \\
\text { Female }\end{array}$ & $\begin{array}{l}75-90 \\
75-90\end{array}$ & $\begin{array}{l}69 \cdot 5 \\
54 \cdot 4\end{array}$ & $\begin{array}{l}17 \cdot 2 \\
12 \cdot 3\end{array}$ & $\begin{array}{l}9 \cdot 1 \\
6 \cdot 9\end{array}$ & $\begin{array}{l}2 \cdot 3 \\
1 \cdot 4\end{array}$ \\
\hline $\begin{array}{l}\text { Vir \& Love, } \\
1979\end{array}$ & $\begin{array}{l}10 \\
27\end{array}$ & $\begin{array}{l}\text { Male } \\
\text { Female }\end{array}$ & $\begin{array}{l}65-89 \\
65-89\end{array}$ & $\begin{array}{r}71 \cdot 7 \\
51 \cdot 9\end{array}$ & $\begin{array}{l}20 \cdot 7 \\
15 \cdot 5\end{array}$ & $\begin{array}{r}10 \cdot 7 \\
7 \cdot 4\end{array}$ & $\begin{array}{l}3 \cdot 4 \\
2 \cdot 3\end{array}$ \\
\hline $\begin{array}{l}\text { DHSS } \\
1979 \mathrm{~b}\end{array}$ & $\begin{array}{l}169 \\
196\end{array}$ & $\begin{array}{l}\text { Male } \\
\text { Female }\end{array}$ & $\begin{array}{l}69-97 \\
69-90\end{array}$ & $\begin{array}{l}70 \cdot 4 \\
55 \cdot 7\end{array}$ & $\begin{array}{l}16 \cdot 2 \\
13 \cdot 3\end{array}$ & $\begin{array}{l}9.0 \\
6.9\end{array}$ & $\begin{array}{l}2 \cdot 2 \\
1 \cdot 7\end{array}$ \\
\hline $\begin{array}{l}\text { Housebound: } \\
\text { Present study }\end{array}$ & $\begin{array}{r}7 \\
13\end{array}$ & $\begin{array}{l}\text { Male } \\
\text { Female }\end{array}$ & $\begin{array}{l}70-85 \\
71-83\end{array}$ & $\begin{array}{l}46 \cdot 3 \\
39 \cdot 1\end{array}$ & $\begin{array}{r}12 \cdot 5 \\
7 \cdot 0\end{array}$ & $\begin{array}{l}6 \cdot 3 \\
4 \cdot 8\end{array}$ & $\begin{array}{l}1.8 \\
0.9\end{array}$ \\
\hline $\begin{array}{l}\text { Exton-Smith } \\
\text { et al. } 1972\end{array}$ & $\begin{array}{l}10 \\
32\end{array}$ & $\begin{array}{l}\text { Male } \\
\text { Female }\end{array}$ & $\begin{array}{l}>70 \\
>70\end{array}$ & $\begin{array}{l}56 \cdot 8 \\
42 \cdot 3\end{array}$ & - & $\begin{array}{l}7 \cdot 2 \\
5 \cdot 4\end{array}$ & - \\
\hline
\end{tabular}

DHSS, Department of Health and Social Security.

Organization (1973) recommendation of $9.14 \mathrm{mmol} \mathrm{kg} / \mathrm{d}(0.8 \mathrm{~g}$ mixed protein $/ \mathrm{kg}$ per d), were compared with those who consumed less than this amount. There was no difference in the $\mathrm{N}$ retentions of the two groups.

A major difficulty in balance studies, particularly in the elderly, is the separation of faecal and urine samples. Urine is the main excretory pathway of $\mathrm{N}$ and, as the stool sample collection continues after the urine collection is complete, if these faecal samples are contaminated with urine then falsely high faecal $\mathrm{N}$ excretions will be measured. Obviously this need not be a problem in male subjects. As there was no difference between the $N$ retentions of men and women in either group we conclude that any contamination of faecal samples was negligible.

\section{DISCUSSION}

The mean energy intakes of 8.7 and $6.6 \mathrm{MJ} / \mathrm{d}$ found for the healthy men and women respectively approached the British recommended daily amount (RDA) (Department of Health and Social and Social Security (DHSS), 1979a) although the individual intakes of eight women and seven men fell below the recommended level. The mean intakes of 6.3 and $4.8 \mathrm{MJ} / \mathrm{d}$ for the male and female housebound were significantly lower than those of the healthy group with no subject having a daily energy intake in excess of the RDA. The housebound had severely restricted mobility and presumably a decreased requirement for energy. Table 4 shows our findings with the calculated results of other comparable studies 
Table 5. Comparison of studies on the dietary protein level at which positive nitrogen balance is achieved in elderly subjects

\begin{tabular}{|c|c|c|}
\hline Reference & Type of diet & $\begin{array}{c}\text { Predicted mean } \\
\text { protein intake } \\
\text { to achieve } \mathrm{N} \text { balance } \\
\text { (g/kg body-wt per } \mathrm{d})\end{array}$ \\
\hline Watkin et al. 1950 & Rice and fruit & $0 \cdot 35$ \\
\hline $\begin{array}{l}\text { Kountz et al. } 1947 \\
\text { Kountz et al. } 1948 \\
\text { Kountz et al. } 1951 \\
\text { Kountz et al. } 1953\end{array}$ & Mixed protein & $\begin{array}{l}1 \cdot 4-2 \cdot 0 \\
2 \cdot 0 \\
0 \cdot 7 \\
1 \cdot 5\end{array}$ \\
\hline Albanese et al. 1957 & $\begin{array}{l}\text { Self selected, } \\
\text { institutional }\end{array}$ & $0.6-0.8$ \\
\hline Cheng et al. 1978 & Wheat-soya-bean-milk & 0.8 \\
\hline Zanni et al. 1979 & Egg protein & 0.59 \\
\hline Uauy et al. $1978 b$ & Egg protein & $0.7-0.85$ \\
\hline Gersovitz et al. 1982 & Egg protein & $>0.8$ \\
\hline $\begin{array}{l}\text { Present study } \\
\text { Healthy people }\end{array}$ & $\begin{array}{l}\text { Self-selected, } \\
\text { mixed protein }\end{array}$ & 0.97 \\
\hline Housebound people & $\begin{array}{l}\text { Self-selected, } \\
\text { mixed protein }\end{array}$ & $>0.67$ \\
\hline
\end{tabular}

of the elderly carried out in Britain. A true comparison is not really possible because of the different methodologies employed. Calculated energy intakes are thought to overestimate the true value by 7-20\% (Stock \& Wheeler, 1972; Acheson et al. 1980). In addition, our metabolizable energy intakes do not give strictly accurate values, since unavailable carbohydrate should be taken into account (Southgate \& Durnin, 1970).

The meals-on-wheels as delivered contained on average $2.4 \mathrm{MJ}$, which although a little lower than calculated by Davies et al. (1974) is similar to that calculated in other studies (Exton-Smith \& Stanton, 1965; Stanton, 1971; Turner \& Glew, 1982; Kipps \& Thomson, 1984). This value complies with the recommendation that the meals should provide one-third of the RDA for energy (DHSS, 1972). A varying amount of the delivered meal was left uneaten so that a mean of $2 \cdot 1 \mathrm{MJ}$ was actually consumed.

There was no relation between age and energy intake in either of the two groups of people studied. This is consistent with the findings of other workers (Stanton \& Exton-Smith, 1970; Exton-Smith et al. 1972) and shows that ageing per se is not necessarily accompanied by reduced energy intakes, but that the important factor is probably reduced physical activity which is a consequence of a deterioration in health.

The mean daily protein intakes for the healthy men and women were 64.9 and $59.7 \mathrm{~g}$ respectively, similar to those calculated for comparable groups (see Table 4) and in excess of the RDA (DHSS, 1979 $a$ ). The housebound individuals ate less protein $(P<0.001)$ than the healthy people, with the mean daily intakes for men and women of $46 \cdot 3$ and $39 \cdot 1 \mathrm{~g} / \mathrm{d}$ both below the RDA (DHSS, 1979 $a$ ). The meals-on-wheels as supplied provided an average of $19.4 \mathrm{~g}$ protein of which a mean of $16.2 \mathrm{~g}$ was actually consumed. The value of $19.4 \mathrm{~g}$ is lower than that found in other comparable studies (Exton-Smith \& Stanton, 1965; Stanton, 1971; Davies et al. 1975; Turner \& Glew, 1982; Kipps \& Thomson, 1984) and also fails to meet the recommendation that meals-on-wheels should provide a minimum of $25 \mathrm{~g}$ protein/meal (Exton-Smith \& Stanton, 1965). 
The healthy people as a group were in equilibrium for $\mathrm{N}$ with a mean daily intake of $733 \mathrm{mmol}$ (equivalent to $0.97 \mathrm{~g}$ protein $/ \mathrm{kg}$ per d). Previous balance studies in old people eating various diets have provided conflicting results, with daily protein intakes ranging from as little as 0.35 to $2.0 \mathrm{~g} / \mathrm{kg}$ body-weight being found necessary to maintain $\mathrm{N}$ equilibrium (see Table 5). All these studies have their limitations; the earlier ones were not always properly controlled and some of the recent ones included chronically sick subjects. Our subjects were healthy and were eating their usual diets. Therefore it would appear that for healthy elderly people eating a mixed, self-selected diet containing adequate energy, a protein intake of $0.97 \mathrm{~g} / \mathrm{kg}$ body-weight per $\mathrm{d}(11.04 \mathrm{mmol} \mathrm{N} / \mathrm{kg}$ body-weight per $\mathrm{d})$ is sufficient to achieve $\mathrm{N}$ balance. This is not a minimum requirement and lower intakes may also be adequate. These results are in contrast to studies on rats (Widdowson \& Kennedy, 1962 ) and suggest that a negative $\mathrm{N}$ balance is not an inevitable consequence of ageing.

The housebound subjects were not in equilibrium for $\mathrm{N}$, the over-all mean loss of $95 \mathrm{mmol} / \mathrm{d}$ significantly differing from zero retention. The daily $\mathrm{N}$ intake of $475 \mathrm{mmol}$ $(0.67 \mathrm{~g}$ protein $/ \mathrm{kg}$ body-weight per d) was only $65 \%$ of that found in the healthy group. We were not able to distinguish whether this amount was inadequate because it was too low to maintain $\mathrm{N}$ balance or if the housebound people have increased requirements for $\mathrm{N}$. The apparently low energy intake did not appear to be a major factor as shown by the lack of correlation between energy intake and $\mathrm{N}$ balance in these subjects. When only the $\mathrm{N}$ retentions of those housebound subjects eating in excess of $0.8 \mathrm{~g}$ protein $/ \mathrm{kg}$ body-weight per $d$ were compared with those consuming less than this amount, no difference in the retentions was observed. This suggests that in the housebound an apparently adequate protein intake alone may not be sufficient to maintain $\mathrm{N}$ balance and is in keeping with two earlier studies (Uauy et al. 1978b; Gersovitz et al. 1982) which included subjects with chronic disease. It is known that immobilization for long periods with decreased muscular activity will lead to wasting and breakdown of tissue protein (Exton-Smith, 1980); this may be a major factor in the negative $\mathrm{N}$ balance observed in our subjects.

No allowance has been made in the balance calculations for body surface losses of $\mathrm{N}$. It has been estimated that such losses lie in the range of 11-32 mmol/d (Calloway et al. 1971; Zanni et al. 1979; Gersovitz et al. 1982). It is very difficult to estimate an appropriate value as so many factors, including amount of sweating (Zanni et al. 1979) and daily protein intake (Calloway et al. 1971), affect the body surface losses of $\mathrm{N}$. Therefore we have made no estimate of additional miscellaneous losses but accept that our values represent maximal $\mathrm{N}$ balance.

The DHSS (1979 $b$ ) have stated that the housebound are particularly at risk of being malnourished. The results obtained here confirm this. The housebound subjects studied were a heterogeneous group but had over-all low dietary intakes of both energy and protein, and a tendency towards a less protein-dense diet than the healthy people. The cause of the observed negative $\mathbf{N}$ balance in the housebound elderly is not known. Decreased dietary intake of protein and possibly of other nutrients, inactivity and reduction in muscle mass, underlying diseases and medications may all be contributing factors. Although the body has a large capacity for adaptation during short periods of deprivation (Food and Nutrition Board, 1980), continued negative $\mathrm{N}$ balance will not allow the body to meet the extra demands of trauma and illness, and deterioration in health will ensue.

The housebound people in our study were not representative of this group of people as a whole. The more poorly nourished could not be included because the technique demanded a high degree of co-operation, which the frail, confused and very depressed could not give. It is pertinent to note that when our housebound subjects were recontacted 6-12 months after the initial investigation nearly all had deteriorated and were unable to take part in any more studies. We can only speculate as to the extent to which this deterioration might have been delayed if dietary supplements had been given. 
The authors thank our volunteers who participated so willingly, and their general practitioners for giving us permission to study their patients. Financial support from Roussel Ltd, The Wessex Regional Health Authority, The Foundation for Age Research and The Wessex Medical School Trust is gratefully acknowledged.

\section{REFERENCES}

Acheson, K. J., Campbell, I. T., Edholm, O. G., Miller, D. S. \& Stock, M. J. (1980). American Journal of Clinical Nutrition 33, 1147-1154.

Albanese, A. A., Higgins, R. A., Oreto, L. A. \& Zavattaro, D. N. (1957). Geriatrics 12, 465-475.

Armitage, P. (1971). Statistical Methods in Medical Research. Oxford: Blackwell Scientific Publications.

Bunker, V. W., Lawson, M. S. \& Clayton, B. E. (1982). Human Nutrition: Clinical Nutrition 36C, 213-221.

Bunker, V. W., Lawson, M. S. \& Clayton, B. E. (1984). Journal of Clinical Pathology 37, 1353-1557.

Calloway, D. H. \& Margen, S. (1971). Journal of Nutrition 101, $205-216$.

Calloway, D. H., Odell, A. C. F. \& Margen, S. (1971). Journal of Nutrition 101, 775-786.

Cheng, A. H. R., Gomez, A., Bergan, J. G., Lee, T. C., Monckeberry, F. \& Chichester, C. O. (1978). American Journal of Clinical Nutrition 31, 12-22.

Chinn, A. B., Lavik, P. S. \& Cameron, D. B. (1956). Journal of Gerontology 11, 151-153.

Davies, L., Hastrop, K. \& Bender, A. E. (1974). Modern Geriatrics 4, 220-226.

Davies, L., Hastrop, K. \& Bender, A. E. (1975). Modern Geriatrics 5, 12-20.

Department of Health and Social Security (1972). A Nutrition Survey of the Elderly. Report on Health and Social Subjects no. 3. London: H.M. Stationery Office.

Department of Health and Social Security (1979a). Recommended Daily Amounts of Food Energy and Nutrients for Groups of People in the UK. Report on Health and Social Subjects no. 15. London: H.M. Stationery Office.

Department of Health and Social Security $(1979 \mathrm{~b})$. Nutrition and Health in Old Age. Report on Health and Social Subjects no. 16. London: H.M. Stationery Office.

Durnin, J. V. G. A. (1983). In Nutritional Problems of the Elderly, pp. 16-30 [J. C. Somogyi and F. Fidanza, editors]. Basel: S. Karger.

Exton-Smith, A. N. (1980). In Metabolic and Nutritional Disorders in the Elderly, pp. 66-76 [A. N. Exton-Smith and F. I. Caird, editors]. Bristol: John Wright and Sons.

Exton-Smith, A. N. \& Stanton, B. R. (1965). Report of an Investigation into the Dietary of Elderly Women Living Alone. London: King Edward's Hospital Fund.

Exton-Smith, A. N., Stanton, B. R. \& Windsor, A. C. M. (1972). Nutrition of Housebound Old People. London: King Edward's Hospital Fund.

Food and Agriculture Organization/World Health Organization (1973). Energy and Protein Requirements. Technical Report Series no. 522. Geneva: WHO.

Food and Nutrition Board (1980). Recommended Dietary Allowances, 9th revised ed. Washington DC: National Academy of Sciences.

Gersovitz, M., Motil, K., Munro, H. N., Scrimshaw, N. S. \& Young, V. R. (1982). American Journal of Clinical Nutrition 35, 6-14.

Kipps, M. \& Thomson, J. (1984). Nutrition and Food Sciences May/June, 8-10.

Kountz, W. B., Ackermann, P. G., Kheim, T. \& Toro, G. (1953). Geriatrics 8, 63-69.

Kountz, W. B., Hofstatter, L. \& Ackermann, P. G. (1947). Geriatrics 2, 173-182.

Kountz, W. B., Hofstatter, L. \& Ackermann, P. G. (1948). Geriatrics 3, 171-184.

Kountz, W. B., Hofstatter, L. \& Ackermann, P. G. (1951). Journal of Gerontology 6, 20-33.

Lonergan, M. E., Milne, J. S., Maule, M. M. \& Williamson, J. (1975). British Journal of Nutrition 34, 517-527.

Macleod, C. C., Judge, T. G. \& Caird, F. I. (1974). Age and Ageing 3, 158-166.

Miller, D. S. \& Payne, P. R. (1959). British Journal of Nutrition 13, 501-508.

Morgan, D. B. (1983). Annals of Clinical Biochemistry 20, 257-261.

Munro, H. N. (1981). British Medical Bulletin 37, 83-88.

Munro, H. N. (1983). In Nutritional Problems of the Elderly, pp. 61-74. [J. C. Somogyi and F. Fidanza, editors]. Basel: S. Karger.

Scrimshaw, N. S., Hussein, M. A., Murray, E., Rand, W. M. \& Young, V. R. (1972). Journal of Nutrition 102, 1595-1604.

Scrimshaw, N. S., Perera, W. D. A. \& Young, V. R. (1976). Journal of Nutrition 106, 665-670.

Southgate, D. A. T. \& Durnin, J. V. G. A. (1970). British Journal of Nutrition 24, 517-535.

Stanton, B. R. (1971). Meals for the Elderly. A Report on Meals-on-Wheels and Luncheon Clubs in Two North London Boroughs. London: King Edward's Hospital Fund.

Stanton, B. R. \& Exton-Smith, A. N. (1970). A Longitudinal Study of the Dietary of Elderly Women. London: King Edward's Hospital Fund.

Stock, A. L. \& Wheeler, E. F. (1972). British Journal of Nutrition 27, 439-448.

Turner, M. \& Glew, G. (1982). Food Technology July, 46-50.

Uauy, R., Scrimshaw, N. S., Rand, W. M. \& Young, V. R. (1978a). Journal of Nutrition 108, 97-103. 
Uauy, R., Scrimshaw, N. S. \& Young, V. R. (1978 b). American Journal of Clinical Nutrition 31, 779-785.

Vir, S. C. \& Love, A. H. G. (1979). American Journal of Clinical Nutrition 32, 1934-1947.

Watkin, D. M., Froeb, H. F., Hatch, F. T. \& Gutman, A. B. (1950). American Journal of Medicine 9, 441-493.

Widdowson, E. M. \& Kennedy, G. C. (1962). Proceedings of the Royal Society: Biological Sciences 156, 96-108.

Zanni, E., Calloway, D. H. \& Zezulka, A. Y. (1979). Journal of Nutrition 109, 513-524. 